\title{
The study of sclareol in inhibiting proliferation of osteosarcoma cells by apoptotic induction and loss of mitochondrial membrane potential.
}

\author{
Jianfen Gao*, Dezhang Wang, Shenfeng Jing, Sibin Hao, Xiangye Huang, Qingtang Miao \\ Department of Orthopedics, Zhang Qiu People`s Hospital, Zhangqiu, Shandong, China
}

\begin{abstract}
Objective: Sclareol (sclacol) is one organic compound extracted from sage clary plants. Recent study has shown its anti-tumor effects against breast cancer, gastric carcinoma, osteosarcoma and colorectal cancer. Its detailed mechanisms in inhibiting tumor growth, however, remained unknown. This study thus observed the effect of sclareol on the proliferation of osteosarcoma cells, in an attempt to investigate the role of sclarcol on osteosarcoma growth.
\end{abstract}

Patients and methods: MG63 osteosarcoma cell was treated by different concentration of sclarcol. CCK8 assay was used to test its effect on cell proliferation. $\mathrm{LC}_{50}$ value was then determined to obtain optimal treatment dosage. MG63 cells were then divided into control and drug treated group, and were tested for apoptosis using flow cytometry. Rhodamine 123 was used to label mitochondrial membrane potential, which was measured by laser confocal microscope.

Results: CCK8 test results showed that sclareol can inhibit MG63 cell proliferation, with an $\mathrm{LC}_{50}$ value at $11.0 \mu \mathrm{M}$. Flow cytometry results showed the apoptotic cell ratio at $13.8 \%, 24.1 \%$ and 37.3\% after applying 2.0 $\mu \mathrm{M}, 4.0 \mu \mathrm{M}$ and $8.0 \mu \mathrm{M}$ sclareol. Compared to control group, sclareol significantly depressed mitochondrial membrane potential of MG63 cells.

Conclusion: Sclareol can inhibit the proliferation of MG63 cells, and induce cell apoptosis and decrease mitochondrial membrane potential. These results suggested the inhibition of osteosarcoma cells by sclareol via both apoptosis induction and decreasing mitochondrial membrane potential.

Keywords: Sclareol, Cell apoptosis, Mitochondrial membrane potential, Osteosarcoma cells.

Accepted on August 10, 2017

\section{Introduction}

Osteosarcoma is one primary malignant bone tumor commonly seen in children or teenagers, and occupies about $5 \%$ of total childhood tumors [1]. Osteosarcoma is commonly occurred in epiphysis end of long bones such as femora and humeral, and has characteristics such as high malignancy and invasiveness [2]. With abundant blood flow at epiphysis, osteosarcoma cell is predisposed to have distal metastasis via blood circulation, causing treatment difficulty and unfavorable prognosis, and bringing heavy burdens for public health [3].

Recent study has revealed certain anti-tumor effect of sclareol in inhibiting tumor growth such as osteosarcoma, breast cancer, gastric cancer and colorectal carcinoma [4,5]. Sclareol, also named as sclareol, is one di-tert-alcohol firstly extracted from sage clary plants in 1982 and later in other plants [6]. Study has found its $\mathrm{LD}_{50}$ larger than $5000 \mathrm{mg} / \mathrm{kg}$ in mice and rabbits, making it one low toxicity compound
[7]. Meanwhile, active compound using sclareol as material has multiple functions including anti-bacteria, anti-spasmodic and anti-viral, making it one important drug material for synthesizing various drugs and pesticides [8].

Sclareol has high anti-bacterial activity against Staphylococcus aureus, Staphylococcus pidermidis and E. coli [9]. It also had certain anti-inflammation effects besides antibacterial functions [10]. Using sclareol as the basal material, 13-sclareol hydrochloride compound has been synthesized with certain anti-spasmodic functions [11]. Sclareol and its derivatives had cytotoxicity on multiple tumor cells and can inhibit tumor growth [12].

Although having anti-tumor effects, the functional mechanism of sclareol is still unknown. This study thus treated osteosarcoma cells with sclareol solution, to observe the effect of various dosages of drugs on the growth and proliferation of osteosarcoma cells, in an attempt to investigate the functional mechanism of sclareol on osteosarcoma growth. 
Citation: Gao J, Wang D, Jing S, et al. The study of sclareol in inhibiting proliferation of osteosarcoma cells by apoptotic induction and loss of mitochondrial membrane potential. J Med Oncl Ther. 2017;2(2):40-44.

\section{Materials and Methods}

\section{Reagents and equipment}

DMEM medium, fetal bovine serum (FBS) and trypsin were purchased from Gibco (US). DMSO, sclareol and PI dyes were produced by Sigma (US). CCK8 test kit was obtained from Toyobo (Japan). Culture dish was a product of Corning (US). $\mathrm{CO}_{2}$ cell incubator was produced by Thermo (US). Microplate reader was obtained from Bio-tek (US). Flow cytometry equipment was provided by BD Biosciences (US).

\section{Cell line and culture}

MG63 osteosarcoma cells were purchased from Shanghai Cell Biology Institute, Chinese Academy of Sciences. Cells were kept in DMEM medium containing 10\% FBS, and were kept in a humidified chamber with $5 \% \mathrm{CO}_{2}$ at $37^{\circ} \mathrm{C}$.

\section{CCK8 assay}

Cells at log-phase were collected by centrifugation. After re-suspension, cells were inoculated in 96-well plate $\left(1 \times 10^{4}\right.$ per well). The plate was incubated $\mathrm{n}$ a humidified chamber with $5 \% \mathrm{CO}_{2}$ at $37^{\circ} \mathrm{C}$ for $24 \mathrm{~h}$. Gradients concentrations of sclareol $(0.5 \mu \mathrm{M}, 1.0 \mu \mathrm{M}, 5.0 \mu \mathrm{M}, 10.0 \mu \mathrm{M}, 20.0 \mu \mathrm{M}, 40.0$ $\mu \mathrm{M}$ and $80.0 \mu \mathrm{M})$ and blank control / DMSO were applied to cells ( $\mathrm{N}=6$ each group).

At different time points $(24 \mathrm{~h}, 48 \mathrm{~h}$ and $72 \mathrm{~h}$, the medium was removed to rinse cells using PBS. $0.1 \mathrm{~mL} 10 \%$ CCK8 working solution was added into each well for further $2 \mathrm{~h}$ incubation. Absorbance value of each well was measured in a microplate reader at $450 \mathrm{~nm}$ wavelength. Using concentration of sclareol as the horizontal axis, the growth curve of MG63 cells was plotted using absorbance value as the vertical axis. The $\mathrm{LC}_{50}$ value of sclareol was deduced on the growth curve.

\section{Flow cytometry}

MG63 cells were treated with DMSO (control) or sclareol. After $48 \mathrm{~h}$, the medium was removed, following by the digestion by $0.25 \%$ trypsin. Cells were rinsed in DMEM to prepare single cell suspensions, which were centrifuged at $1000 \mathrm{~g}$ for $5 \mathrm{~min}$. PBS was then added to rinse cells again for further centrifugation. Supernatants were removed with adding $0.2 \mathrm{~mL}$ blocking buffer. The mixture was then incubated at room temperature for $15 \mathrm{~min}$. $0.5 \mathrm{~mL}$ buffer solution was then added, followed by centrifugation. 0.2 $\mathrm{mL}$ annexin $\mathrm{V}$ dye was added, mixed and incubated for 10 min. After rinsing and washing by centrifugation, PI dye was added. The mixture was then loaded for flow cytometry to detect apoptosis.

\section{Mitochondrial membrane potential ( $(\Psi)$ analysis}

Cells were digested in $0.25 \%$ trypsin, and were rinsed to prepare single cell suspension, which was centrifuged at $1000 \mathrm{~g}$ for $5 \mathrm{~min}$. DMEM medium was then added to prepare single cell suspension $\left(1 \times 10^{6}\right.$ per $\left.\mathrm{mL}\right)$, which was then mixed with $10 \mu \mathrm{L}$ Rhodamine 123 dye. Cells were incubated in a humidified chamber with $5 \% \mathrm{CO}_{2}$ at $37^{\circ} \mathrm{C}$ for 1 h. 0.1 $\mathrm{mL}$ cell suspensions were added on glass slide to observe fluorescence intensity (FI) under a laser confocal microscope at $488 \mathrm{~nm} / 590 \mathrm{~nm}$ wavelength for the quantification of $\Delta \Psi$.

\section{Statistical analysis}

SPSS 20.0 software was used to process all collected data. Measurement data were presented as mean \pm standard deviation (SD) and were compared by analysis of variance (ANOVA). Enumeration data were presented as percentiles and were analyzed by chi-square method. A statistical analysis was defined when $\mathrm{p}<0.05$.

\section{Results}

\section{Effect of sclareol on MG63 cell proliferation}

MG63 osteosarcoma cells were divided into control, DMSO and experimental group, which received no treatment, DMSO treatment and gradient concentration of sclareol $(0.5$ $\mu \mathrm{M}, 1.0 \mu \mathrm{M}, 5.0 \mu \mathrm{M}, 10.0 \mu \mathrm{M}, 20.0 \mu \mathrm{M}, 40.0 \mu \mathrm{M}$ and 80.0 $\mu \mathrm{M})$. After $24 \mathrm{~h}, 48 \mathrm{~h}$ or $72 \mathrm{~h}$, CCK8 method was used to determine the effect of drug on MG63 cell proliferation. As shown in, low dosage sclareol $(<=5.0 \mu \mathrm{M})$ had relatively less significant effects on cell proliferation, while high dosage drug $(>5.0 \mu \mathrm{M})$ significantly inhibited MG63 cell proliferation. Under the same concentration of drug, the proliferation ability of cells was weakened with prolonged treatment time $(\mathrm{F}=17.82, \mathrm{p}<0.05)$. By approximation, $\mathrm{LC}_{50}$ values of sclareol on MG63 cells were $18.8 \mu \mathrm{M}, 11.0 \mu \mathrm{M}$ and $6.3 \mu \mathrm{M}$ at $24 \mathrm{~h}, 48 \mathrm{~h}$ and $72 \mathrm{~h}$, respectively. These results suggested the inhibition of sclareol on MG63 cell proliferation (Figure 1).

\section{Sclareol induced MG63 cell apoptosis}

To study the mechanism of sclareol on inhibiting MG63 cell proliferation, we further investigated the effect of sclareol on MG63 cell apoptosis. We divided cells into DMSO group and treatment group, which were further sub-divided into 2.0 $\mu \mathrm{M}, 4.0 \mu \mathrm{M}$ and $8.0 \mu \mathrm{M}$. $48 \mathrm{~h}$ after treatment, flow cytometry was used to measure cell apoptosis. As shown in, sclareol may induce MG63 cell apoptosis, with apoptotic cell ratio at 13.8\%, $24.1 \%$ and $37.3 \%$ for $2.0 \mu \mathrm{M}, 4.0 \mu \mathrm{M}$ and $8.0 \mu \mathrm{M}$ of sclareol, respectively. DMSO-treated cells, however, had apoptotic cell ratio at $5.1 \%$. Significant difference existed between control and experimental group $(\mathrm{F}=22.65, \mathrm{p}<0.05)$ (Figure 2).

\section{Effect of sclareol on mitochondrial membrane potential $(\Delta \Psi)$}

Rhodamine 123 (Rh123) is one cation florescent

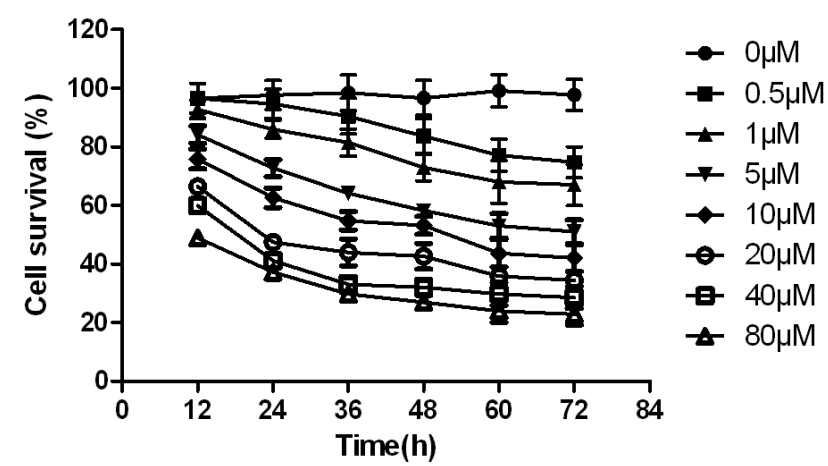

Figure 1. Effect of sclerol on MG63 cell proliferation. 

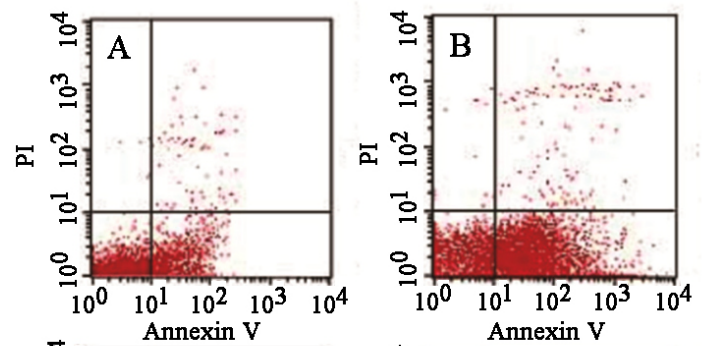

E
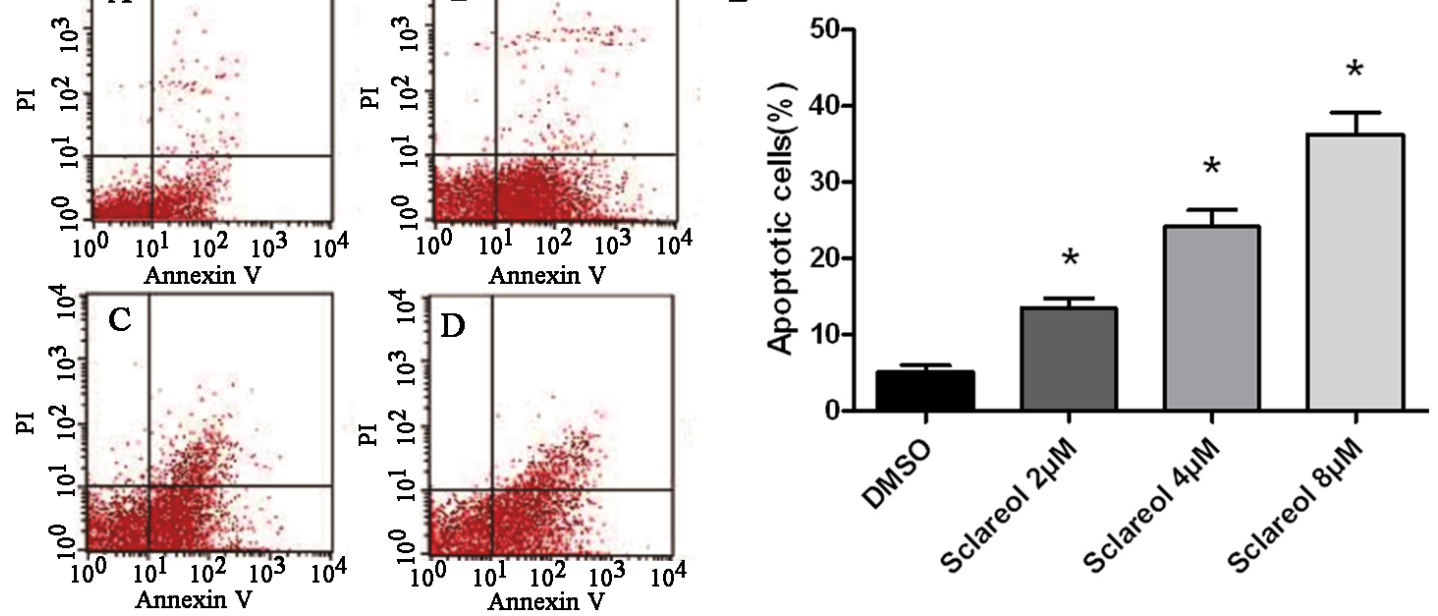

Figure 2. Sclerol induced MG63 cell apoptosis. A to D, flow cytometry for apoptosis in MG63 cells treated with DMSO (A), $2 \mu M$ sclerol (B), $4 \mu \mathrm{M}$ sclerol (C) and $8 \mu \mathrm{M}$ sclerol (D).

$*, p<0.05$ compared to control group

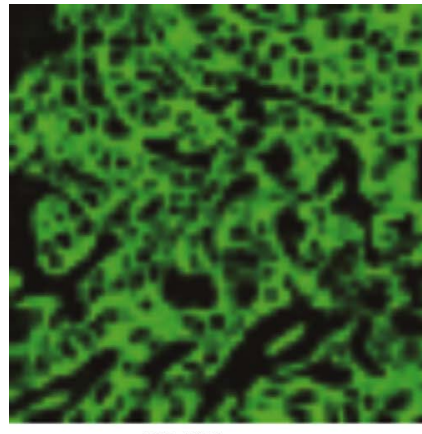

DMSO

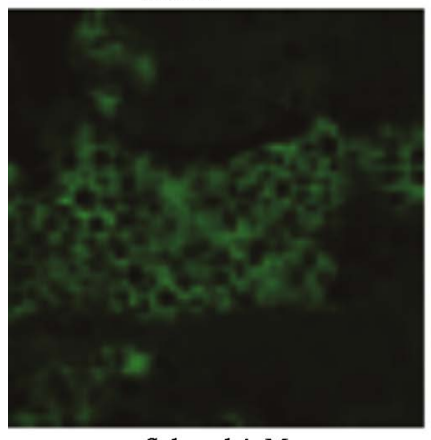

Sclareol $4 \mu \mathrm{M}$

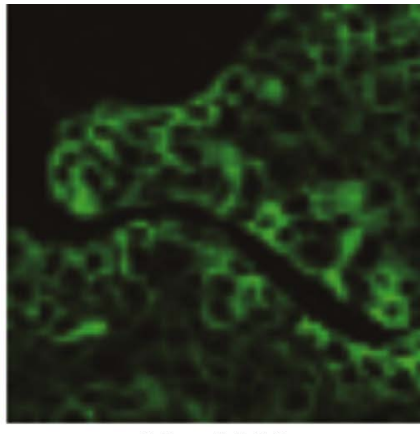

Sclareol $2 \mu \mathrm{M}$

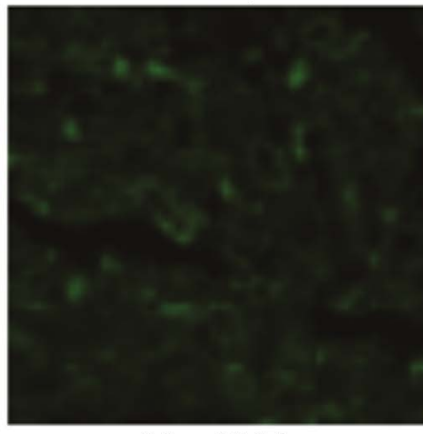

Sclareol $8 \mu \mathrm{M}$

Figure 3. Sclerol's effect on mitochondrial membrane potential.

dye that is dependent on mitochondrial membrane potential $(\Delta \Psi)$. By observing the florescent intensity emitted by Rh123, one can determine the alternation of $\Delta \Psi$ and apoptosis. Therefore we utilized laser confocal microscope to observe the change of $\Delta \Psi$. We divided cells into DMSO group and treatment group, which were further sub-divided into $2.0 \mu \mathrm{M}, 4.0 \mu \mathrm{M}$ and $8.0 \mu \mathrm{M} .12$ $\mathrm{h}$ after treatment, cells were observed under microscope. As shown in, MG63 cells had significantly depressed $\Delta \Psi$ in sclareol treated cells. There was a negative correlation between sclareol concentration and $\Delta \Psi$, indicating that sclareol could decrease mitochondrial membrane potential of MG63 cells (Figure 3).

\section{Discussion}

Sclareol is one di-tert-alcohol firstly extracted from sage clary plants, which are mainly distributed in China and Mediterranean regions [13]. Traditionally it was used to produce perfumes and additives and also as materials for drug development [14]. Previous reports indicated the antitumor activity of sclareol as it showed inhibitory effects on osteosarcoma, breast cancer, gastric carcinoma and colorectal carcinoma, but leaving its mechanism largely unknown [15]. To study the anti-tumor activity of sclareol, we selected MG63 osteosarcoma cell as the model, on which the effect of sclareol on cell viability was observed using CCK8 assay. All cells were divided into blank control, solvent control and experimental group.

Test results showed decreased proliferation ability of cells after treating using sclareol. Within certain dosage range, there was a negative correlation between sclareol concentration and cell viability. Under the same concentration of drugs, the proliferation ability of MG63 cell was decreased with elongated treatment. To further study the mechanism underlying sclareol inhibition on osteosarcoma cells, we divided cells in to DMSO and sclareol group, on which flow cytometry was used to test cell apoptosis. Our results showed significantly elevated apoptotic cell ratio in treatment group comparing to DMSO treated cells $(\mathrm{p}<0.05)$. With higher concentration of sclareol, the apoptotic percentage of MG63 cells was gradually increased, supporting the induction of osteosarcoma cell apoptosis by sclareol.

However, the mechanism underlying apoptosis of MG63 cells induced by sclareol is still unknown. Previous literature showed certain role of mitochondria in cell apoptosis, whose membrane potential has close relationship with cell apoptosis [16]. As one organelle with double lipid membrane, mitochondria are the main location for producing 
energy of cell aerobic respiration. It also participates in signal transduction and cell apoptosis, with regulatory role on cell growth and cell cycle [17]. Recent study has shown the decrease of mitochondrial membrane potential may change permeability of membrane and induce further apoptosis [18]. Therefore cell apoptosis can be observed by measuring the membrane potential of mitochondria. Rh123 is one anion fluorescent dye with membrane permeability. It can enter into mitochondria in a trans membrane potential dependent manner to decrease or quench fluorescent intensity under normal condition [19].

When cell apoptosis occurs, Rh123 can be released from mitochondria for illuminating fluorescent. Therefore the membrane potential and cell apoptosis can be detected by measuring fluorescent intensity [20]. To further illustrate the molecular mechanism underlying sclareol-induced apoptosis, we divided MG63 cells into both DMSO and sclareol treated group, on which the effect of sclareol on membrane potential of cells was observed under laser confocal microscope. Results showed significantly depressed mitochondrial membrane potential of sclareol-treated MG63 cells compared to DMSO-treated ones $(p<0.05)$. Higher dosage of sclareol had more significantly depressed membrane potential, suggesting the role of sclareol in decreasing mitochondrial membrane potential in osteosarcoma cells.

In summary, sclareol can decrease mitochondrial membrane potential of MG63 osteosarcoma cells and alter mitochondrial biological functions, thus inducing cell apoptosis and inhibiting osteosarcoma cell growth and proliferation.

\section{Acknowledgement}

The authors declare no competing financial or commercial interests in this manuscript.

\section{References}

1. Jemal A, Bray F, Center MM, et al. Global cancer statistics. CA Cancer J Clin. 2011;61(2):69-90.

2. Osborne TS, Khanna C. A review of the association between osteosarcoma metastasis and protein translation. J Comp Pathol. 2012;146(2-3):132-42.

3. Yang J, Zhang W. New molecular insights into osteosarcoma targeted therapy. Curr Opin Oncol. 2013;25(4):398-406

4. Zhong Y, Huang Y, Santoso MB, et al. Sclareol exerts anti-osteoarthritic activities in interleukin-1-beta-induced rabbit chondrocytes and a rabbit osteoarthritis model. Int J Clin Exp Pathol. 2015;8(3):2365-74.

5. Shakeel U, Rah B, Lone SH, et al. Design and synthesis of antitumor heck-coupled sclareol analogues: Modulation of BH3 family members by SS-12 in autophagy and apoptotic cell death. J Med Chem. 2015;58(8):3432-44.
6. Huang GJ, Pan $\mathrm{CH}, \mathrm{Wu} \mathrm{CH}$. Sclareol exhibits antiinflammatory activity in both lipopolysaccharidestimulated macrophages and the lambda-carrageenaninduced paw edema model. J Nat Prod. 2012;75(1):54-9.

7. Noori S, Hassan ZM, Mohammadi M, et al. Sclareol modulates the Treg intra-tumoral infiltrated cell and inhibits tumor growth in vivo. Cell Immunol. 2010;263(2):148-53.

8. Noori S, Hassan ZM, Salehian O. Sclareol reduces CD4+ CD25+ FoxP3 + Treg cells in a breast cancer model in vivo. Iran J Immunol. 2013;10(1):10-21.

9. Ulubelen A, Miski M, Johansson C, et al. Terpenoids from Salvia palaestina. Phytochemistry. 1985;24(6):1386-7.

10. Little BJ, Gerke TL, Lee JS. Mini-review: The morphology, mineralogy and microbiology of accumulated iron corrosion products. Biofouling. 2014;30(8):941-8.

11. Juan MC, Sofia S, Joaquin A. 8 $\alpha, 13$-Epoxy14,15-dinorlabd-12-ene (SclareolOxide) $[(+)-(4 \mathrm{aR}, 6 \mathrm{As}, 10 \mathrm{As}, 10 \mathrm{bR})-3,4 \mathrm{a}, 7,7,10 \mathrm{a}-$ Pentamethyl4a,5,6,6a, 7,8,9,10,10a,10b-decahydro-1H-benz-o[f $]$ chromene]. Molbank. 2003;2003(4):304.

12. Demetzos C, Pippa N. Advanced drug delivery nanosystems (aDDnSs): A mini-review. Drug Deliv. 2014;21(4):250-7.

13. Ma M, Feng J, Li R, et al. Synthesis and antifungal activity of ethers, alcohols and iodohydrin derivatives of sclareol against phytopathogenic fungi in vitro. Bioorg Med Chem Lett. 2015;25(14):2773-7.

14. Fujimoto T, Mizukubo T, Abe H, et al. Sclareol induces plant resistance to root-knot nematode partially through ethylene-dependent enhancement of lignin accumulation. Mol Plant Microbe Interact. 2015;28(4):398-407.

15. Bhatia SP, McGinty D, Letizia CS, et al. Fragrance material review on sclareol. Food Chem Toxicol. 2008;46:S270-4.

16. Zhang XJ, Mei WL, Tan GH, et al. Strophalloside induces apoptosis of SGC-7901 cells through the mitochondrion-dependent caspase-3 pathway. Molecules. 2015;20(4):5714-28.

17. Wang P, Luo C, Li Q, et al. Mitochondrion-mediated apoptosis is involved in reproductive damage caused by BPA in male rats. Environ Toxicol Pharmacol. 2014;38(3):1025-33.

18. He D, Zhang H, Yang P. The mitochondrion-located protein OsB12D1 enhances flooding tolerance during seed germination and early seedling growth in rice. Int $\mathbf{J}$ Mol Sci. 2014;15(8):13461-81.

19. Al-Mohizea AM, Al-Jenoobi FI, Alam MA. Rhodamine-123: A p-glycoprotein marker complex with sodium lauryl sulfate. Pak J Pharm Sci. 2015;28(2):617-22. 
20. Parasrampuria R, Shaik IH, Mehvar R. Effects of in vivo hepatic ischemia-reperfusion injury on the hepatobiliary disposition of rhodamine 123 and its metabolites in isolated perfused rat livers. J Pharm Pharm Sci. 2012;15(2):318-28.

\section{*Correspondence to:}

Dr. Jianfen Gao

Department of Orthopedics

Zhang Qiu People`s Hospital

Zhangqiu

Shandong

China.

Tel: +86-13969168338;

Fax: +86-13969168338;

E-mail: gaojianfenfda@163.com 